\title{
木材トレーサビリティの簡易的手法に関する研究 \\ 一中部山岳域の四地域における実証実験一 \\ A STUDY ON SIMPLE METHOD OF THE WOOD TRACEABILITY
}

Demonstration in 4 areas of the Japanese Alps

西谷風香*, 添原洋平**, 浅野良晴***, 岩井一博****, 早川慶朗*****

\section{Fuka NISHITANI, Yohei SOEHARA, Yoshiharu ASANO, Kazuhiro IWAI and Yoshiaki HAYAKAWA}

\begin{abstract}
In this study, in order to consider the method of the wood traceability system, we conducted verification tests in 4 areas. Furthermore, we conducted hearing survey at each distribution process in order to extract the necessary information about the wood.

From the tests, we verified that the electronic tag labels are useful in wood traceability.

In addition, through the hearing survey, we obtained the necessary information about the wood that is required by forestry cooperatives, the lumber market, and sawmills.

Then, we considered a simple method of wood traceability system which based on those results.
\end{abstract}

Keywords : Wood, Traceability, Distribution, Quality

木材，トレーサビリティ，流通，品質

\section{1.はじめに}

現在わが国の人工林は今後 10 年間で約 6 割が利用可能な高齢級の 森林に移行する見込みである。森林の多面的機能の維持のためにも 国内の森林資源を有効利用していく必要がある ${ }^{11}$ 。

「公共建築物等における木材の利用の促進に関する法律」の制定 やプレカットの普及などにより、産地や無等級材以上の強度、寸法 安定性といった品質の明らかな材が必要とされている。ほとんどの 地域で木材の産地証明を行う認証材制度が存在し、また一部の地域 では強度等の品質についても認証を行っている ${ }^{2)}$ 。しかし多くの国 産材は産地や強度等の品質が明らかにされていないのが現状である。

この状態を解決する手法として木材トレーサビリティシステムが 挙げられる。これは、一つの材が出来るまでのすべての工程で加工・ 流通情報を蓄積し、それを素材生産者、加工者、消費者等で共有す るシステムである。図 1 のように木材トレーサビリティの情報を共 有できることで、木材流通の需要側の建築業者などにとっては、リ アルタイムで、流通している材の場所、品質、量、価格が確認でき る。これにより、工事の日程管理や費用の見積もりがしやすくなる。 また、森林組合や製材工場といった供給側の業者としては、品質保
証、産地証明だけでなく需要側の注文に合わせた生産の計画立てが 可能となる。それにより、各流通段階での流通の効率化や在庫の低

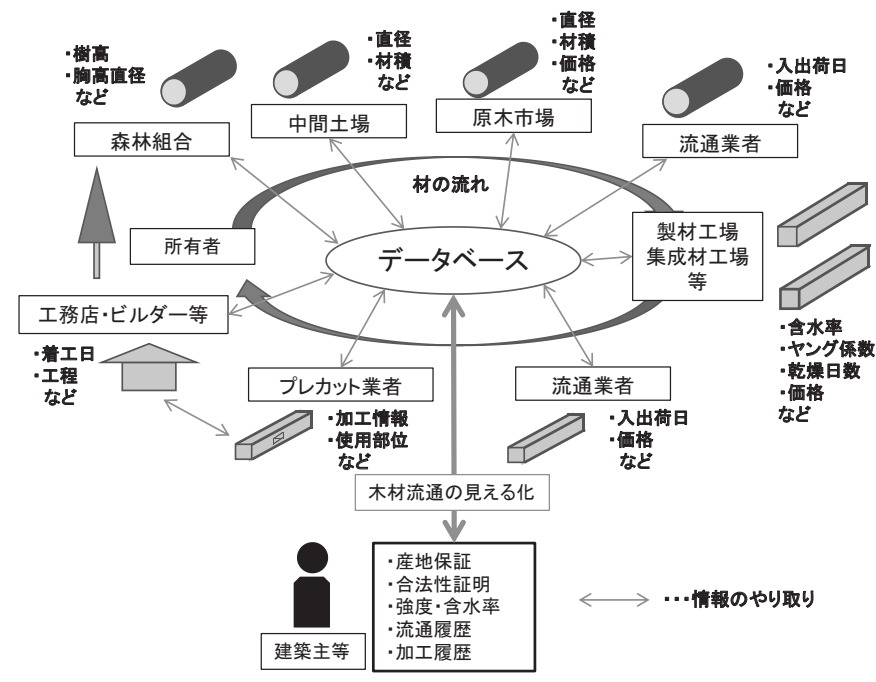

図 1 木材流通の流れとデータベースの位置づけ
* 信州大学大学院理工学系研究科建築学専攻 大学院生

** 元信州大学大学院理工学系研究科建築学専攻 大学院生

*** 信州大学学術研究院工学系 教授. 工博

**** 信州大学学術研究院工学系 准教授・博士 (工学

***** (侏) Andeco 代表取締役・博士(工学)
Grad. Stud., Dept. of Architecture, Faculty of Engineering, Shinshu University Former Grad. Stud.., Dept. of Architecture, Faculty of Engineering. Shinshu University Prof., Institute of Engineering Academic Assembly, Shinshu University, Dr.Eng. Assoc. Prof., Institute of Engineering Academic Assembly, Shinshu University, Dr.Eng. CEO, Andeco inc., Dr.Eng. 
減、加工寸る際の歩留まりの向上等が期待できる。これにより木材 の品質の向上や需給のマッチングを進め、また中大規模木造建築物 の設計や材料調達の際に必要とされる各流通段階での在庫量を明確 にすることで、国産材の利用が促進されると考える。

同システムについて全国の 8 グループが試行し、木材のトレーサ ビリティの確立に成功しており、またその有用性を実証している ${ }^{3)}$ 。 しかし作業量の増加などによる生産コストの増加に対し、有効な効 果が見いだせないなどといった問題点の解決が課題であるとしてい る ${ }^{3)}$ 。現在、木材トレーサビリティシステムが広く普及していると は言えない。導入へのハードルを下げ、木材トレーサビリティシス テムの普及を促進させる必要があると考える。

トレーサビリティ情報に関しては、中村らは、木材流通トレーサ ビリティシステムなどのシステムの導入・実装により実現させなけ ればいけないこととして「含水率、ヤング率、及び産地が木材個材 ごとに、トレースできうる情報として表示されること」年を挙げて いる。本論ではこれらに加え、現状で各業者が共通して把握してい る情報を最低限必要な情報と定義し、聞き取り調查をもとに必要な 情報を明らかにする。

\section{2. 研究概要}

本論文では、トレーサビリティを確保させるための作業を簡易に する手法を明らかにすること、また建物の評価に関わる木材の寸法、 強度、含水率、材面の美観、産地、合法性、生産履歴を担保し、木 材流通上において最低限必要とされるトレーサビリティ情報を明ら かにすることを目的とする。

3 章では既往の検証 ${ }^{3)}$ において実証された手法の問題点を明らか にした上で、予備実験として 3 地域で新たな実証実験を行った。そ れはすでに実証された手法を踏襲した形で実施した。その結果を踏 まえ、トレーサビリティを確保させるための作業をより簡易にする 手法を明らかにすることを目的とした。すなわちデータキャリア、 取り扱うデータの内容とその取得方法に焦点を当てて簡易化の検討 をし、4 章の本実験へとつなげた。

また 5 章では、木材流通上において最低限必要とされるトレーサ ビリティ情報を明らかにすることを目的とし、木材流通の各工程で ヒアリング調查を行った。そこから現状で取り扱っている情報並び に、さらに把握することで効果があると考えられる情報を明確にし、 取り扱うデータの内容の検討を行った。

\section{3. 予備実験について}

\section{1 実験方法}

実験は長野県根羽村、長野県信濃町、新潟県加茂市の 3 箇所にお いて行った。今回の実験では、熱可塑性の樹脂加工が施された UHF 帯 RFID タグ（以下電子タグ）（写真 1）と、耐水紙または耐水ラベ ルにレーザープリンターで印字した QR コード（写真 2）をデータ キャリアとして使用した。電子タグはサイズが $3 \mathrm{~cm} \times 12 \mathrm{~cm}$ (×厚み $2 \mathrm{~cm}$ )、動作周波数は $860 \sim 960 \mathrm{MHz}$ 、動作温度範囲は $-40^{\circ} \mathrm{C} \sim+70^{\circ} \mathrm{C}$ 、 通信距離は $5 \mathrm{~m}$ である。QR コードのサイズは $5 \mathrm{~cm} \times 5 \mathrm{~cm}$ 程度である。 これにより木材に ID を与え、管理をする。電子タグはタッカーに より固定し、QR コードはタッカーにより固定またはシール状のも のを貼り付けた。データキャリアの情報はリーダライター（写真 3)
により読み取った。リーダライターは携帯情報端末であり、データ の編集、保存ができるものを使用した。

実験の流れを図 2 に、使用したデータ項目を表 1 に示す。倒木の 前後からデータキャリアを取り付け、その ID で材の管理を行う。 木材流通の各過程で、表 1 に示すデータを蓄積していき、最終的に トレーサビリティが確保されたか確認をした。今回使用したデータ 項目は、既往の検証 ${ }^{3)}$ において使用されたものを参考にしている。 丸太のサンプル数は、長野県根羽村で 17 本、新潟県加茂市で 12 本、 長野県信濃町で 6 本である。長野県根羽村においては、丸太の 4 本 に電子タグを、1 13 本にQR コードを取り付けた。

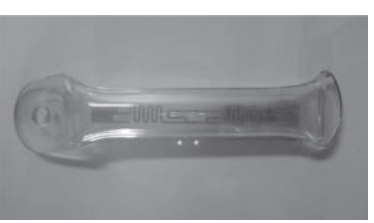

写真 1

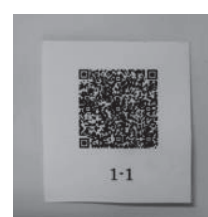

写真 2

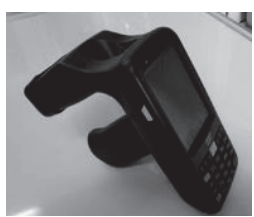

写真 3
電子タグ (樹脂加エ)

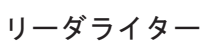

表 1 実験で使用したデータ項目

\begin{tabular}{|c|c|c|}
\hline 位置情報 & 作業情報 = 加工情報 & 個体情報 \\
\hline \multicolumn{3}{|c|}{ 林地 } \\
\hline 方位 & 植生 & |樹種 \\
\hline 林分区分 & 地拵日 & 材積 \\
\hline 林班-小班·地番·施業番号 & 植栽本数 & 樹高 \\
\hline 地位 & 植栽年月日 & 胸高直径 \\
\hline 立木位置 & 傾斜 & 材質 \\
\hline 所有者名 & 作業年月日(下刈り) & 樹齢 \\
\hline 出材地 & 作業年月日(間伐) & 出荷価格 \\
\hline \multirow[t]{5}{*}{ 出材年月日 } & 作業年月日(枝打ち) & \\
\hline & 間伐強度 & \\
\hline & 林分本数 & \\
\hline & 林分面積 & \\
\hline & 林分材積 & \\
\hline \multicolumn{3}{|c|}{ 中間土場 } \\
\hline 土場入荷日 & 出材者 & 材長 \\
\hline 土場位置 & 伐採年月日 & 樹皮外観 \\
\hline 所有者名 & 伐採者 & 玉切数 \\
\hline 会社名 & 倒木方向 & 原木等級 \\
\hline 出材地 & 造材日 & 末口径 \\
\hline \multirow{4}{*}{ 出材年月日 } & 伐採確認者 & 径級 \\
\hline & 気温 & 材質 \\
\hline & 葉枯期間 & ヤング係数 \\
\hline & & 出荷価格 \\
\hline \multicolumn{3}{|c|}{ 原木市場 - 流通業者 } \\
\hline 入荷年月日 & |はい積み年月日 & 径級 \\
\hline 会社名 & 運送業者 & 材質 \\
\hline 出材地 & & 材長 \\
\hline 出材年月日 & & はい積み材積 \\
\hline \multirow{3}{*}{ はい積み位置 } & & はい積み材質 \\
\hline & & 腐り等特記事項 \\
\hline & & 出荷価格 \\
\hline \multicolumn{3}{|c|}{ 製材工場 } \\
\hline 入荷年月日 & 皮剥ぎ作業年月日 & 購入価格 \\
\hline 工場名 & 作業者名 & 材積 \\
\hline 皮剥ぎ前丸太在庫位置 & 粗挽き製材作業年月日 & 皮剥ぎ後径 \\
\hline 皮剥ぎ後丸太在庫位置 & 作業者名 ～～～～～～～ & 粗挽き製材後形状寸法 \\
\hline 粗挽き製材前丸太在庫位置 & 人工乾燥作業年月日 & 乾燥前含水率 \\
\hline 粗挽き製材後丸太在庫位置 & 作業者名 & 製材後形状寸法 \\
\hline 人工乾燥用材在庫位置 & 人工乾燥終了日 & 人工乾燥後含水率 \\
\hline 複数回乾燥用材在庫位置 & 自然乾燥作業年月日 & 自然乾燥後含水率 \\
\hline 人工乾燥済み製材品在庫位置 & 自然乾燥作業終了日 & 仕上げ後形状寸法 \\
\hline 自然乾燥用材在庫位置 & 仕上げ作業年月日 & ヤング係数 \\
\hline 自然乾燥済み製材品在庫位置 & 作業者名 & ヤング係数計測年月日 \\
\hline 仕上げ作業後丸太在庫位置 & & 出荷価格 \\
\hline 出荷先 & & 製品等級 \\
\hline 出材年月日 & & 材積 \\
\hline \multicolumn{3}{|c|}{ プレカットエ場 } \\
\hline 入荷年月日 & 加工年月日 & ヤング係数 \\
\hline 購入元 & 加工者名 & 製品加工情報 \\
\hline 工場名 & & 含水率 \\
\hline 加工済み製品在庫位置 & & 出荷価格 \\
\hline 出荷先 & & \\
\hline 出荷年月日 & & \\
\hline
\end{tabular}




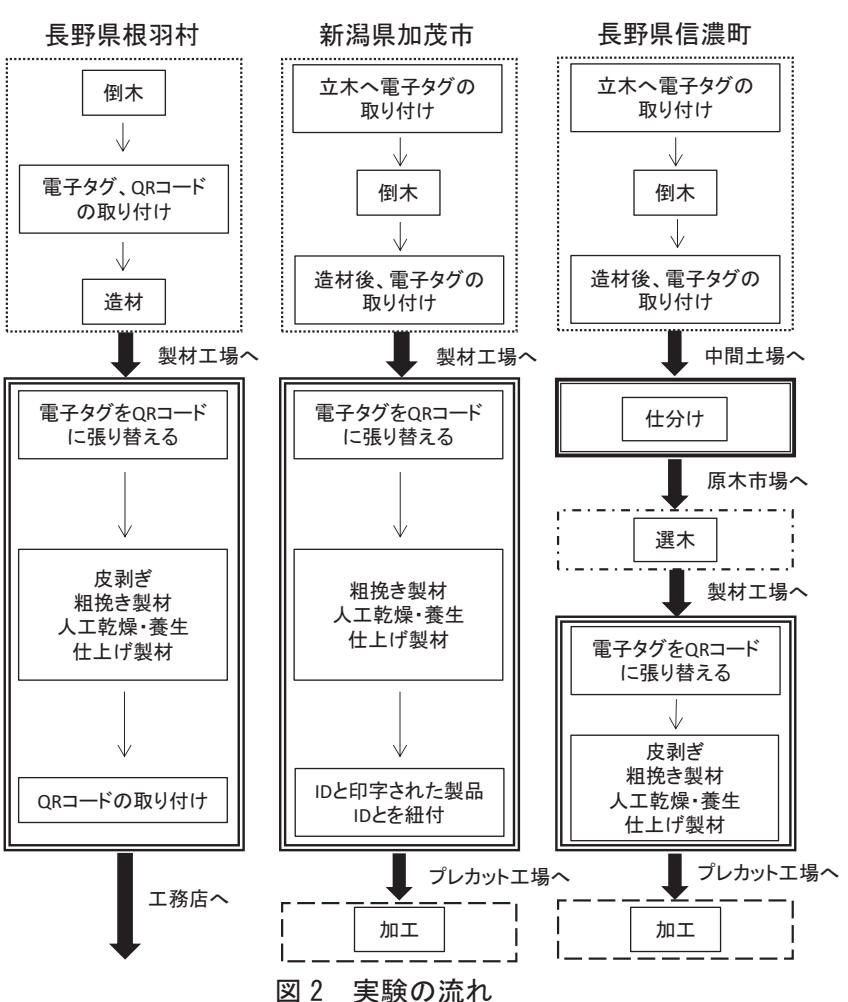

\section{2 実験結果}

表 2 にデータキャリアについての実験結果を示す。結果の評価方 法については、全ての対象の材において使用できたもののみ○とし、 その他はメとした。製材工場における仕上げ製材後の製品 No.の印

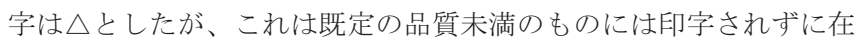
庫になることから、材によっては追跡が不可能という評価である。

長野県根羽村では、製材工場において乾燥が行われるまでの期間 風雨に曝され、新潟県加茂市では、製材工場において乾燥が行われ るまでの期間、長野県信濃町では、造材されてから製材される前ま での期間、材は雪と風雨に曝されていた。

電子タグは、倒木、搬出後も読み取ることが可能であった。外部 からの衝撃に耐えることができ、複数回の使用に十分な頑健性が確 認された。このことから、再利用も可能であると考えられる。八ー ベスタ等の林業機械、原木市場の選木機を使う際には、電子タグを 木材からいったん取り外す必要があった。これは電子タグの形状が 大きく、厚みがあったために、取り付けたままでは機械に通せなか ったからである。複数回の着脱作業が必要となり、作業性に難点が あると言える。造材後の木材の木口に電子タグを取り付けた様子を 写真 4 に示す。

$\mathrm{QR}$ コードは、燻煙式乾燥の場合に台紙が変色し、読み取ること ができなくなった。燻煙式乾燥後の QR コードの様子を写真 5 に示 す。また、固定方法については、タッカーを用いた場合、製材機の 刃を損傷する恐れがある。製材前に取り外寸必要があり、作業性が 悪い。シール状のものは、木材が湿っている場合や蒸気式乾燥を行 う場合に剥離が見られた。途中でデータを失う可能性があり、信頼 性の観点から使用は難しい。

データ項目については、林地における傾斜や中間土場における原 木等級など、実験場所では考慮されていない項目があった。また、 実験中の聞き取りにより、納期や材面の美観、背割りの有無などの

情報が必要であることが明らかとなった。必要とされる項目には、 各流通過程で一般的に必要とされるものと、地域や流通形態によっ て異なるものとがある。意義のある情報蓄積・情報共有がなされる ように、最低限必要なデータ項目を定義する必要がある。

表 2 データキャリアの実験結果

\begin{tabular}{|c|c|c|c|c|c|c|c|c|}
\hline \multirow{2}{*}{\multicolumn{3}{|c|}{ 実験工程 }} & \multicolumn{2}{|c|}{ 新潟県加茂市 } & \multicolumn{2}{|c|}{ 長野県信濃町 } & \multicolumn{2}{|c|}{ 長野県根羽村 } \\
\hline & & & \multirow{2}{*}{$\begin{array}{c}\begin{array}{c}\text { データ } \\
\text { キャリア }\end{array} \\
\text { 電子タグ }\end{array}$} & \multirow{2}{*}{$\begin{array}{c}\text { 結果 } \\
0\end{array}$} & \multirow{2}{*}{$\begin{array}{c}\begin{array}{c}\text { データ } \\
\text { キャリア }\end{array} \\
\text { 電子タグ }\end{array}$} & \multirow{2}{*}{$\begin{array}{c}\text { 結果 } \\
\end{array}$} & \multirow{2}{*}{$\begin{array}{l}\text { データ } \\
\text { キャリア }\end{array}$} & \multirow{2}{*}{$\begin{array}{l}\text { 結果 } \\
- \\
\end{array}$} \\
\hline \multirow{13}{*}{$\begin{array}{l}\text { 作 } \\
\text { 業 } \\
\text { 場 } \\
\text { 所 } \\
\text {. } \\
\text { 工 } \\
\text { 程 }\end{array}$} & \multirow{3}{*}{ 林地 } & 倒木·搬出 & & & & & & \\
\hline & & \multirow[b]{2}{*}{ 造材後 } & \multirow[b]{2}{*}{ 電子タグ } & \multirow[b]{2}{*}{ ○ } & \multirow[b]{2}{*}{ 電子タグ } & \multirow[b]{2}{*}{ O } & 電子タグ & $\mathrm{O}$ \\
\hline & & & & & & & $\begin{array}{l}\text { QRコード } \\
\text { (タッカー) }\end{array}$ & O \\
\hline & \multirow{3}{*}{ 土場 } & \multirow{2}{*}{$\begin{array}{c}\text { データ } \\
\text { キャリア } \\
\text { の貼り替え }\end{array}$} & $\begin{array}{l}\text { QRコード } \\
\text { (タッカー) }\end{array}$ & $x$ & & - & $\begin{array}{l}\text { QRコード } \\
\text { (タッカー) }\end{array}$ & $x$ \\
\hline & & & $\begin{array}{l}\text { QRコード } \\
\text { (ラベル) }\end{array}$ & $x$ & & - & $\begin{array}{l}\text { QRコード } \\
\text { (ラベル) }\end{array}$ & ○ \\
\hline & & $\begin{array}{c}\text { 貼り替え } \\
\text { なし }\end{array}$ & - & - & 電子タグ & O & - & - \\
\hline & 原木市場 & 選木 & 一 & - & 電子タグ & $x$ & 一 & 一 \\
\hline & \multirow{5}{*}{ 製材工場 } & 皮剥ぎ & - & - & $\begin{array}{l}\text { QRコード } \\
\text { (タッカー) }\end{array}$ & $\mathrm{O}$ & $\begin{array}{l}\text { QRコード } \\
\text { (ラベル) }\end{array}$ & ○ \\
\hline & & $\begin{array}{c}\text { 粗挽き } \\
\text { 製材 }\end{array}$ & $\begin{array}{l}\text { QRコード } \\
\text { (ラベル) }\end{array}$ & $x$ & $\begin{array}{l}\text { QRコード } \\
\text { (タッカー) }\end{array}$ & $\mathrm{O}$ & $\begin{array}{l}\text { QRコード } \\
\text { (ラベル) }\end{array}$ & $\bigcirc$ \\
\hline & & 乾燥 (燻煙) & $\begin{array}{l}\text { QRコード } \\
\text { (タッカー) }\end{array}$ & $x$ & - & - & - & - \\
\hline & & 乾燥 (蒸気) & - & - & $\begin{array}{l}\text { QRコード } \\
\text { (タッカー) }\end{array}$ & O & $\begin{array}{l}\text { QRコード } \\
\text { (ラベル) }\end{array}$ & $x$ \\
\hline & & $\begin{array}{l}\text { 仕上げ } \\
\text { 製材後 }\end{array}$ & $\begin{array}{l}\text { 製品No. } \\
\text { の印字 }\end{array}$ & $\Delta$ & - & - & - & - \\
\hline & $\begin{array}{c}\text { プレカット } \\
\text { エ場 }\end{array}$ & プレカット & $\begin{array}{l}\text { 製品No. } \\
\text { の印字 }\end{array}$ & $x$ & - & - & 一 & - \\
\hline
\end{tabular}

4. 本実験について

4. 1 データキャリアの改善についての実験

4. 1 . 1 実験方法

実験は岐阜県高山市において行った。使用したデータキャリアを 写真 6 に示す。これは、サイズが $1.1 \mathrm{~cm} \times 2.5 \mathrm{~cm}$ で厚みの無いラベ

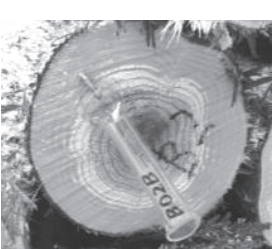

写真 4 電子タグを 取り付けた様子

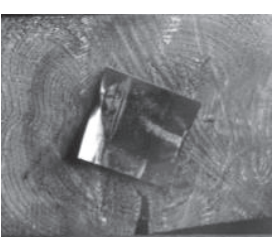

写真 5 燻煙式乾燥後 の $Q R$ コードの様子

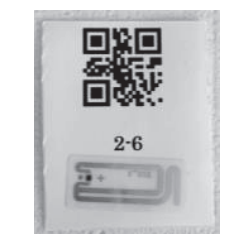

写真 6 岐阜県で使用 したデータキャリア
岐阜県高山市

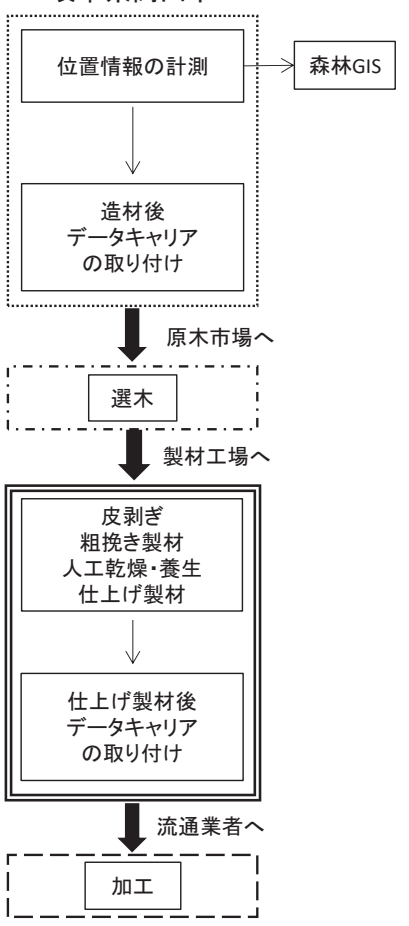

図 3 実験の流れ 
ル状の UHF 帯電子タグを、台紙に貼り付けたものである。電子夕 グの動作周波数は 860 960MHz、動作温度範囲は $-40^{\circ} \mathrm{C} \sim+85^{\circ} \mathrm{C}$ 、 通信距離は $60 \mathrm{~cm}$ である。今回はこれを造材後の木口に接着剂を用 いて固定した。実験の流れは図 3 に示寸通りである。今回は、立木 時の情報は森林 GIS から得るために、林地では伐採地の位置情報を 取得し、木材の造材後から電子タグを取り付け、追跡を開始した。 丸太のサンプル数は 9 本である。

\section{1.2 実験結果}

林地においては積雪があり、周りの雪が造材後の木口に付着し木 ロが湿っていたが、接着剤によりデータキャリアを取り付けること は可能であった。森林 GIS を利用し情報を得ることとしたため、林 地における電子タグの取り付け作業は、造材後のはい積みされた材 に対して行った。倒木の前後に電子タグを取り付けた場合、造材時 の ID の引継ぎに手間がかかった。それに対し、まとめられた木材 に対しての取り付けは作業性が容易であった。

今回の実験では、製材工場の土場に入荷後、積雪により材を見失 ってしまった。材の木口に付着した雪が凍っており、雪を落とす際 に、雪と共にデータキャリアも落ちてしまった可能性がある。積雪 時の対応について、再度検証が必要である。

製材機のチャックによる損傷や、蒸気式乾燥の高温状態による損 傷は見られず、ID を読み取ることが可能であった。このことから、 林地における造材後から仕上げ製材時の幅切りまで一貫して使用で きることが明らかとなった。林業機器や選木機、製材機を使用する 場合においても着脱作業が不要であり作業性が良い。データキャリ アの着脱が無いことで信頼性も確保できるため、有用性が高いと考 える。

乾燥後に電子タグのラベルの粘着力が落ちてしまうため、再利用 は難しい。その点が克服できれば安価でかつ有用性の高いデータキ ヤリアとなりうる。

\section{2 データの取得方法について}

岐阜県における実証実験では、林地においての立木情報の取得を 簡易化するために、森林 GIS の情報を使用した。森林 GIS によっ て得られる情報を表 3 に示す。施業地では位置情報のみ取得してお くことで、森林 GIS により森林の面積や樹種、所有者、林齢などの 出材地の概要を入手することができる。また、地位、林齢、樹種に より統計值(林分収穫表)から、樹高や胸高直径、材積などの立木時 の情報を推定することが可能である。これらの森林資源量のデータ は個人情報であるため一般に公開寸ることは難しい。そのため所有 者・素材生産者が把握した中で、各需要者の必要に応じて、限定的 に公開すべきである。

林地において立木一本ごとに情報を搭載する詳細な方法に比べ、 森林 GIS を使用することで、 5 章で述べる木材トレーサビリティの 情報として必要な、樹種、出在地の情報は容易に紐付けが可能であ る。作業性の悪い林地での計測、データの入力等の作業量の低減に つながる。

胸高直径や樹高等の立木情報は、現状の森林 GIS データから得ら れるものと現実とでは乘離が大きい。しかし、これらの情報が共有 できれば、施業中あるいは施業前の森林から生産可能な材を把握で
き、材の調達や設計時の部材決定が容易になると考えられる。また、 素材生産者にとっては施業前の現地調査の作業が省略可能となり、 さらに生産可能な材の情報と需要側の情報を合わせて見ることで、 計画的な木材生産が可能になる。これらの効果を得るためには、航 空写真の画像解析技術や、3 次元レーザースキャナ 5)等により、地 理情報と結び付けた森林資源量等データの、さらなる精度の向上が 望まれる。胸高直径は $2 \mathrm{~cm}$ 単位、樹高は $1 \mathrm{~m}$ 単位で計測されるため、 それらの単位の範囲内の精度となれば、共有する情報として有効で あると考える。

表 3 森林 GIS の使用により得られる情報

\begin{tabular}{|c|l|l|}
\hline 公開範囲 & \multicolumn{2}{|c|}{ データ } \\
\hline \multirow{5}{*}{ 一般公開 } & 林小班 & $* * *$ \\
\cline { 2 - 3 } & 森林区分 & 民有林 \\
\cline { 2 - 3 } & 人工林·天然林分布 & 人エ林 \\
\cline { 2 - 3 } & 植生分布 & クロマツ \\
\cline { 2 - 3 } & 樹種 & スギ \\
\cline { 2 - 3 } & 人工林齢級分布 & $10 \sim 12$ 齢級 \\
\cline { 2 - 3 } & 層区分 & 上層木 \\
\hline \multirow{3}{*}{ 非公開* } & 森林所有者 & $* * *$ \\
\cline { 2 - 3 } & 地位 & 4 \\
\cline { 2 - 3 } & 蓄積量 & $20.2 \mathrm{~m}$ \\
\hline \multirow{2}{*}{ によ地位·林齢·樹種 } & 樹高 & 25.8 \\
\cline { 2 - 3 } & 胸高直径 & $0.534 \mathrm{~m}^{3}$ \\
\cline { 2 - 3 } & 材積 & ヒノキ14 $\mathrm{m}^{3}$ \\
\hline
\end{tabular}

*非公開 $\cdots$ 研究目的や森林の管理者、森林の所有者は申請により取得できる

\section{5. 取り扱いデータの内容に関する調査}

\section{1 調査方法}

3 章の実験地である長野県内の素材生産者 2 件、原木市場 1 件、 製材工場 1 件にヒアリング調查を行った。材に関して必要と寸る情 報、各生産・流通過程で現在把握されている情報を明らかにした。 調査対象先の特徵を表 4 に示す。

\section{表 4 調査場所の特徵}

\begin{tabular}{|c|c|}
\hline 調査場所 & 特徵 \\
\hline N森林組合 & $\begin{array}{l}\text { ·素材生産量 } 5,000 \mathrm{~m}^{3} / \text { 年 } \\
\text { ·自社製材工場 ( } \mathrm{N} \text { 製材工場)を持ち、製材用素材は基本的に } \\
\text { 自社で使用 } \\
\text { ·その他の材については原木市場へ出荷 } \\
\text { ·工務店の顧客を持ち、基本的には受注生産 }\end{array}$ \\
\hline H森林組合 & $\begin{array}{l}\cdot \text { ·素材生産量 } 31,000 \mathrm{~m}^{3} / \text { 年 } \\
\text { ·基本的には原木市場を通して素材を流通させる } \\
\text { ·製材工場への直送にも対応 }\end{array}$ \\
\hline H原木市場 & $\begin{array}{l}\text { ·年間取扱量 } 50,000 \mathrm{~m}^{3} \text { 程度 } \\
\cdot \text { ·トック可能量 } 4,000 \mathrm{~m}^{3} \text { 程度 } \\
\text { ·製材用などの良質な材を対象とした受託販売と、合板用材等 } \\
\text { を対象とした買い取り販売を行う }\end{array}$ \\
\hline N製材工場 & $\begin{array}{l}\text { ·製品出荷量 } 1,500 \mathrm{~m}^{3} \\
\cdot \text {-素材の調達は全て自社( } \mathrm{N} \text { 森林組合)から行う } \\
\text { ·務店の顧客を持ち、基本的には受注生産 } \\
\text { ·JAS目視等級、地域材認証制度を取得 }\end{array}$ \\
\hline
\end{tabular}

\section{2 調査結果}

（1）製材までの取り扱い項目について

$\mathrm{N}$ 及び $\mathrm{H}$ 森林組合、 $\mathrm{H}$ 原木市場、 $\mathrm{N}$ 製材工場の各流通過程で現在 把握されている情報を表 5, 6, 7 に示す。その他必要とされる情報、 把握により生産性の向上等が期待できる情報を表 8 に示す。

$\mathrm{N}$ 及び $\mathrm{H}$ 森林組合では、森林資源量は施業前に現地調査を行うこ とでおよその量を把握している。それを元に伐採計画等が立てられ 
ている。現地調査のコストを低減するために、正確な森林資源量の データ化が望まれている。

また、 $\mathrm{N}$ 及び $\mathrm{H}$ 森林組合では伐採日や造材日等の情報は、施業期 間等に基づいておよその期間で把握されている。これは材の劣化を 防ぐために把握されているもので、日単位での正確な把握や、川下 への情報の共有はされていない。 $\mathrm{H}$ 原木市場や $\mathrm{N}$ 製材工場において は、残地期間の長い材は丸太の木口や樹皮等の外観からの判断によ り、販売・購入が避けられている。これは残地期間の長い材は、虫 食いや腐り等の欠点を内包するリスクが高くなるからである。

施業履歴は現状では一般的には把握できない。場所によっては、 森林計画図や補助事業の履歴を遡ることで、数十年分の履歴を把握 することも可能である。施業履歴は次に施す施行の時期や内容の適 正化を図るために必要とされている。 $\mathrm{H}$ 森林組合は、丸太へ施業履 歴を紐付けることで、名産地では他地域産材との差別化につながる 可能性を指摘した。 $\mathrm{N}$ 製材工場からは、枝打ち等の履歴から節の出 やすさといった丸太の材質の判断基準となりうるとの指摘があった。

また、丸太とそこから取れた製品情報が紐付けられ、情報が蓄積 されていくことで、丸太から取れる製品が推定できると考えられる。 $\mathrm{N}$ 森林組合から、採材時の選択肢の増加など生産性の向上につなが る可能性があると指摘があった。

これらのことから、現状は目視で判断している丸太や立木の特徴 を一定の基準に基づいて評価をし、トレーサビリティ情報として蓄 積していくことで、森林資源の計画的な利用や生産性の向上、流通 の効率化などに結びつく可能性がある。現状においては森林資源量 や施業履歴等はデータ化がされておらず、これらの整備が望まれる。 以上より、現状でヒアリング対象とした業者が各流通工程で共通 して把握しており、素材流通段階において取り扱うべきと考える情 報は、素材検地前では出在地(産地)、樹種であり、素材検地以降は 樹種、産地、末口直径、材長、曲り、欠点、材積、合法性である。

\section{（2）製材以降の取り扱い項目について}

JAS 等の認証制度や CASBEE 等の建築物の評価制度に関わり、 建築主や建築業者が必要とする情報を表 8 に示す。示した項目の内、 寸法、強度、材面の美観、産地は、工務店から要望がある項目とし て N 製材工場へのヒアリング調査においても挙げられていた。寸法、 強度、含水率、保存処理、材面の美観については、JAS あるいは地 域材など認証制度により規定があるため、それら認証の取得の有無 を明確にした上で品質を表示する必要がある。そのような認証の取 得がない場合は、強度については無等級材として基準強度を示し、 その他の項目については、計測方法や使用機械等、詳細な生産履歴 を表示することで信頼性を確保する必要がある。

以上のことから、製材品については表 9 に示した項目について詳 細に示すことで、木材の生産履歴と品質を担保するべきと考える。

（1）、（2）に示した情報を蓄積することで、目的として挙げた、 建物の評価に関わる木材の寸法、強度、含水率、材面の美観、産地、 合法性、生産履歴は担保されると考えるが、価格情報については木 材の取引に絡み、示寸べきかどうか建築業者へのヒアリングを行う べきと考える。
表 5 N， H 森林組合が把握している情報

\begin{tabular}{|c|c|c|}
\hline \multicolumn{2}{|c|}{ 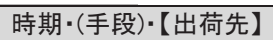 } & 把握されているデータ \\
\hline \multirow{2}{*}{ 施業前 } & (森林簿) & ·樹種·林齢·面積·所有者 \\
\hline & (現地調査) & ·胸高直径·樹高·材積·林分密度 \\
\hline \multirow[b]{2}{*}{ 施業時 } & 造材後 & ·所有者·樹種·倒木時期 \\
\hline & 仕分け時 & $\begin{array}{l}\text { ·所有者·出材地·樹種·搬出時期·材長 } \\
\text { ·末口直径·曲以·年 }\end{array}$ \\
\hline \multirow[b]{2}{*}{ 出荷時 } & 【原木市場】 & $\begin{array}{l}\text { - 所有者·出材地 ·樹種 - 出材者·搬出時期 } \\
\text { - 合法性 }{ }^{* 1}\end{array}$ \\
\hline & 【製材工場】 & $\begin{array}{l}\text { ·所有者·出材地 ·樹種·材長·末口直径·曲り } \\
\text {-欠点·出材者·搬出時期·価格·材積·合法性 }{ }^{* 1} \\
\text {-出荷先 }\end{array}$ \\
\hline
\end{tabular}

*1事業者認定を受けている事業者のみ

表 6 H 原木市場が把握している情報

\begin{tabular}{|c|c|}
\hline 時期 & 把握されているデ一タ \\
\hline 入荷時 & -所有者·出材地(産地)·出材者·樹種 ·合法性 ${ }^{* 1}$ \\
\hline 素材検知 & $\begin{array}{l}\text { ·所有者·出材地(産地)·出材者·樹種·合法性 }{ }^{* 1} \text { ·材長 } \\
\text { ·末口直径·材積·曲り }\end{array}$ \\
\hline はい積み後 & -樹種·末口直径·材長·本数·材積·合法性*1.曲り·尔点 \\
\hline 丸太在庫 & -樹種·末口直径·材長·本数·材積·合法性*1.曲り·尔点 \\
\hline 出荷時 & $\begin{array}{l}\text {-樹種·末口直径·材長·本数·材積·合法性 }{ }^{* 1} \cdot \text { 曲り·尔点 } \\
\text { - 価格·出荷先 }\end{array}$ \\
\hline
\end{tabular}

表 $7 \quad \mathrm{~N}$ 製材工場が把握している情報

\begin{tabular}{|c|c|}
\hline 時期 & 把握されているデ一タ \\
\hline 入荷時 & $\begin{array}{l}\text { ·樹種·末口直径·材長·材積·曲り·尔点·産地 }{ }^{* 1} \\
\text { ·合法性 }{ }^{* 1} \cdot \text { 価格·本数 }\end{array}$ \\
\hline 丸太在庫 & $\begin{array}{l}\text { ·樹種·末口直径·材長·材積·曲り·尔点·産地 }{ }^{* 1} \\
\text { ·合法性 }{ }^{* 1} \cdot \text { 本数 }\end{array}$ \\
\hline 製品在庫 & 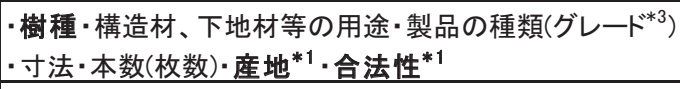 \\
\hline 出荷時 & $\begin{array}{l}\text { ·樹種·製品の種類(製品のグレ一ド*2)·寸法·本数(枚数) } \\
\text { ·産地"1 ·価格·合法性 }{ }^{* 1} \cdot \text { 材面の美観·強度*3 }\end{array}$ \\
\hline
\end{tabular}
*1 工場に使用する全ての材の調達を自社の素材生産で行っているため把握 している

*2 JAS目視等級·地域材認証制度を取得しておりその格付けによる

*3 グレーディングマシンを所有しており必要に応じて計測している

表 8 必要とされる情報 - その他効果が期待できる情報

\begin{tabular}{|c|c|c|}
\hline 場所 & 必要とされる情報 & $\begin{array}{c}\text { その他把握による効果が } \\
\text { 期待できる情報 }\end{array}$ \\
\hline \multirow{4}{*}{ H,N森林組合 } & 産地 & \multirow{4}{*}{ - } \\
\hline & 正確な森林資源量 & \\
\hline & 需要の情報 & \\
\hline & 施業履歴 & \\
\hline \multirow{2}{*}{ H原木市場 } & 産地 & \multirow{2}{*}{-} \\
\hline & 需要の情報 & \\
\hline \multirow{4}{*}{ N製材工場 } & 産地 & 丸太と取れた製品の紐付け \\
\hline & 需要の情報 & 施業履歴 \\
\hline & \multirow{2}{*}{ - } & 伐採日·造材日等の丸太の生産履歴 \\
\hline & & 正確な森林資源量 \\
\hline
\end{tabular}

表 9 建築物の評価制度に係わる情報 建築物の評価制度に係わる情報

\begin{tabular}{|l|l|}
\hline \multicolumn{2}{|c|}{ 建築物の評価制度に係わる情報 } \\
\hline 寸法 & 保存処理 \\
\hline 強度(JAS規格によるもの) & 産地 \\
\hline 含水率 & 合法性 \\
\hline 材面の美観(節·背割り·攵点等) & 流通履歴 \\
\hline 樹種 & 乾燥方法·期間等の生産履歴 \\
\hline
\end{tabular}




\section{6. 木材トレーサビリティ確保のための簡易的な手法の考察}

前章までの実験、調查の結果を踏まえ、本論で提案する木材のト レーサビリティ確保のための簡易的な手法について以下に記す。

立木時の情報は立木一本ごとに情報を搭載し、タグの取り付けは 材一本単位に、立木時あるいは倒木時に行う詳細な手法に対し、簡 易的な手法としては、立木時の情報を森林 GIS から得ることと、タ グの取り付けをロット単位で行う、原木市場または中間土場で材が 仕分けられた後に行うということが挙げられる。これらの簡易化を 行う場合の特徵として次のことが挙げられる。

(1) 素材流通において、丸太はロット単位で管理されている。タグ 等の取り付けをロット単位で行うことで、取り付け作業の省力 化を図ることができる。

(2) タグ等の取り付けを、原木市場あるいは中間土場で材が用途別 に仕分けられた後に行うことで、トレーサビリティ情報が必要 な材にのみタグを取り付けることが可能となる。

(3) 森林 GIS の利用、(1), (2) に示寸作業量の低減化を図った場合、 立木時以外の情報に関しては詳細な場合と変わらず得ることが 可能である。立木時の情報は、簡易化した場合は郡単位の情報 として得ることとなり、単木毎の詳しい胸高直径、樹高の情報 の把握が難しくなる。

(4) 必要とされる情報によっては現状以上に材を分けて管理しなけ ればならず、広大なストックヤードが必要になる。

以上 4 点を踏まえ、木材のトレーサビリティを簡易的に確保する
手法を検討し、木材トレーサビリティシステムの普及を促進するこ とが重要である。

実証実験やヒアリング調查を踏まえ、本論文で提唱する木材トレ 一サビリティシステムのフロー図を図 4 に示す。現在、木材の流通 情報を一括で管理している機関はない。信頼性のある情報とするた めに、適切な生産履歴として管理する認証機関が必要である。木材 トレーサビリティ情報の蓄積・閲覧はこの認証機関を通して行う。

認証機関となりうる組織については今後調查を行う必要があるが、 この組織は生産側と需要側の情報を管理する役割を担う。今回木材 トレーサビリティシステムの実証実験を行った岐阜県では、システ ム販売という販売形式をとっている。これは並材については木材の 需要者が希望する材を希望する量だけ山元で生産し、需要者に直送 するという形式で、安定供給につながっている。原木市場の一部を ストックヤードとして中間土場のように使っており、山から直送で きないものは、そこから需要者へ送っている。生産側と需要側の情 報はここが取りまとめており、この岐阜県の流通形態においては、 認証機関の役割を原木市場が賄うということが例として挙げられる。 また、山元と製材業者、製材業者と建築業者の間で材を管理してい るという点で、流通業者も認証機関となりうる組織の例として挙げ られると考える。

作業効率については、丸太は、林地・中間土場・原木市場におい て、産地・合法性・樹種によって明確に管理されている。各流通上 において、これらの中の最終地点からタグ等を取り付けることで、
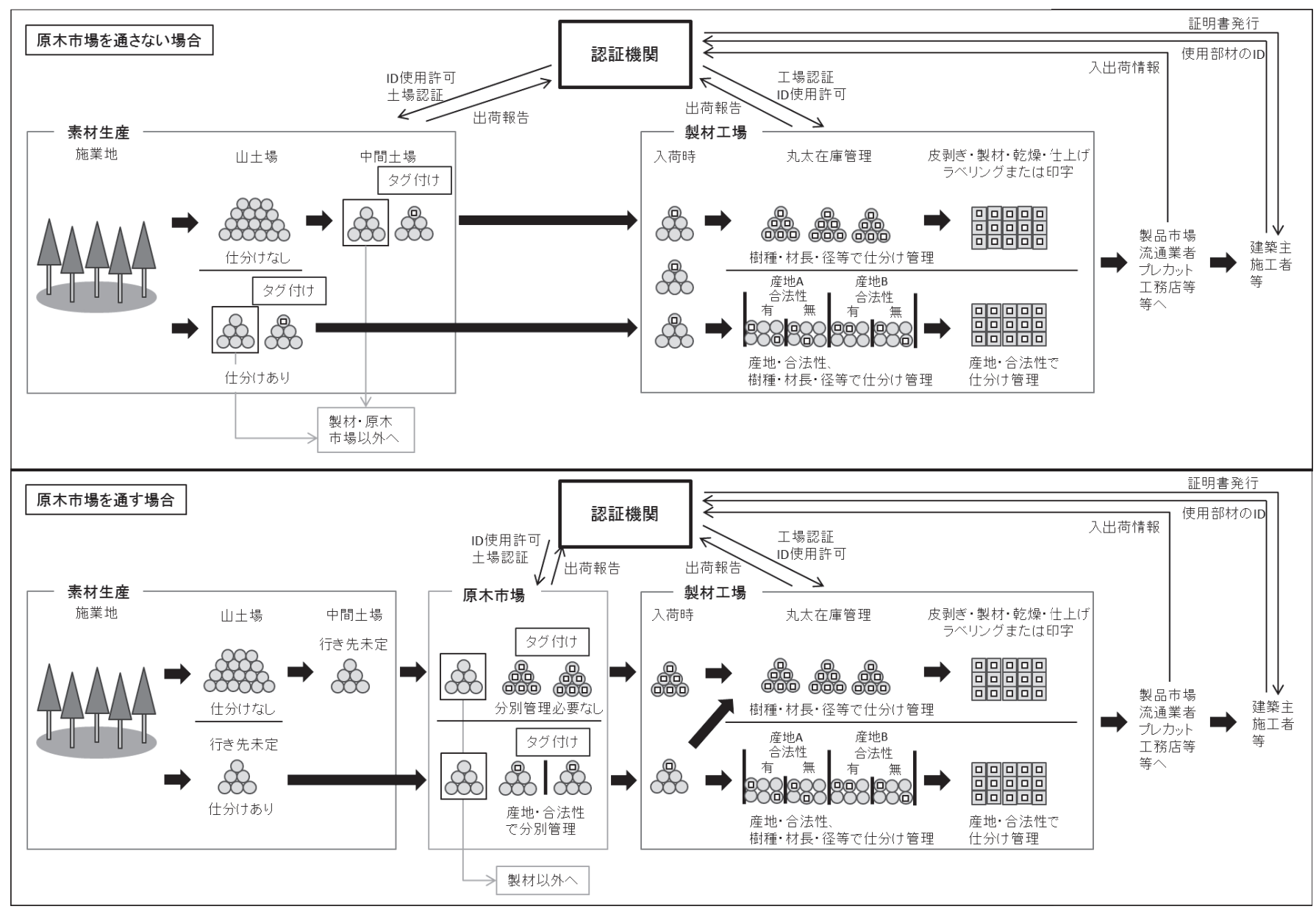

図 4 本論文で提唱する製材用木材のトレーサビリティ確保のための手法 
トレーサビリティの確保を簡易的に行うことができる。また、仕上 げ製材の段階では、寸法・強度等、材の品質を明示する必要がある ため、単木単位でのラベリングや材への印字等が必要である。

分別管理を行う場合は、タグ等の取り付け作業を減らすことがで きる。信頼性の観点から、第三者機関による流通・加工体制の認証 等が必要である。また、素材流通段階における情報は産地、合法性 の有無、樹種という、分別単位のものとなる。

原木市場や製材工場において、ストックヤードの面積が不十分で あるなどの理由から、丸太や製品の在庫を分別管理できない場合も 考えられる。その場合は、単木単位でタグ等を取り付ける必要があ る。タグを取り付ける手間はかかるが、材を混ぜても各情報を高精 度に明示できる。

以上のような手法をとることで、建築用の製材品として使用され る木材に限定して追跡をすることができる。また、ロット単位での 管理を取り入れることで、タグ等の取り付け作業を最小限に抑える ことが可能となる。

\section{7. まとめと今後の課題}

本研究では木材流通上において最低限必要とされるトレーサビリ ティ情報を明らかにし、木材のトレーサビリティを簡易に確保する 手法の検討を行った。作業の簡略化、信頼性を確保するための適切 なデータキャリアや使用するデータ項目について、実証実験とヒア リング調查を行い、得られた知見を以下に示す。

1）ラベル状の電子タグは、流通の川上から川下まで一貫して使用 でき、トレーサビリティを確保することを実証した。これによ り、作業量の低減・信頼性の確保の観点から、データキャリア としてラベル状の電子タグは有用であると考える。

2）位置情報から森林 GIS データを取得することで、郡単位での立 木時の情報を得ることができる。これにより、産地や立木時の 情報を材に容易に紐付けることができ、林地における作業量の 低減につながる。

3）今回のヒアリング調查において各業者が共通して把握している 情報は、素材検知までは出在地(産地)、樹種であり、それ以降は 樹種、産地、径、材長、曲り、欠点、材積、合法性であった。 これらが素材流通において必要となる情報となると考える。

4）製品流通において必要となる情報は、10 項目あり、それらは寸 法、樹種、産地、強度、合法性、材面の美観、含水率、保存処
理、流通履歴、生産履歴である。これらの情報は、JAS や地域 材等の認証取得の有無を明記したうえで搭載する必要がある。

5）本論で示したトレーサビリティ情報として必要となる情報は、 原木市場や中間土場から材の追跡を開始寸る手法や、ロット単 位での管理によっても搭載が可能である。これらの手法を取り入れ ることで最小限のタグ等の取り付け作業で、必要なデータを取り扱 うことができると考える。

今後の課題としては、本論文で示した簡易的な木材トレーサビリ ティ確保のための手法の実証、ラベル状電子タグの積雪下での再度 検証が挙げられる。また、今回はヒアリング調查の範囲が長野県内 の施設にとどまっており、限定的な範囲でのシステムの提案となっ た。今後ヒアリング調查を全国に拡張し、今回示した情報が他地域 でも適用可能か確認し、より一般的なものとしていく必要がある。 また同時に、今回示したラベル状電子タグをデータキャリアとして 使用した場合の使用性についても、ヒアリングをする必要がある。 データ項目については建築業者に対してもヒアリングを行い、今回 示した情報が適切か検討を行う必要がある。

\section{謝辞}

最後に本研究を進めるにあたって多大なるご協力をくださった関 係各位の皆様に謝意を表します。

\section{参考文献}

1）林野庁, ”平成 24 年版 森林・林業白書”，2013.06, (オンライン) http://www. rinya. maff. go. jp/j/kikaku/hakusyo/24hakusyo/index. ht m1，（参照 2016-3-28）

2) 窪江優美ほか 3 名 : 県産材認証の現状と課題一認証制度に関するアンケ 一ト調査の結果より一, 東京農業大学農学集報 58(4), pp199-206, 20 14.3

3）一般社団法人木を活か寸建築推進協議会・株式会社 DCMC, “地域材利 用加速化支援事業のうち地域材実用化促進対策事業 トレーサビリティ システム確立検証＼cjkstart報告書”，2011.03，（オンライン） http://www.k iwoikasu. or. jp/technology/s01. php?no=43, 2011. 05. 31，（参照 2016-3 -28)

4）中村裕幸ほか: 国内人工林再生のための品質・商流・物流マネジメント システムの普及・展開 その 1 , オンデマンド型木材流通システム, 日本建築学会大会学術講演梗概集, F-1 分冊, pp1563-1564, 2009.7

5）早川慶朗ほか:木材のカスケード利用に向けた可搬型 3 次元レーザース キャナによる木材資源量算定-長野県北信エリアのスギの事例-, 日本 建築学会計画系論文集, vol.79, no. 703, pp2109-2116, 2014.09, （才 ンライン) https://www. jstage. jst.go.jp/article/aija/79/703/79_2 109/_pdf, （参照 2016-3-28） 


\title{
A STUDY ON SIMPLE METHOD OF THE WOOD TRACEABILITY
}

Demonstration in 4 areas of the Japanese Alps

\section{Fuka NISHITANI*, Yohei SOEHARA**, Yoshiharu ASANO ***, Kazuhiro IWAI**** and Yoshiaki HAYAKAWA ****}

\author{
* Grad. Stud., Dept. of Architecture, Faculty of Engineering, Shinshu University \\ ** Former Grad. Stud., Dept. of Architecture, Faculty of Engineering, Shinshu University \\ *** Prof., Institute of Engineering Academic Assembly, Shinshu University, Dr.Eng. \\ **** Assoc. Prof., Institute of Engineering Academic Assembly, Shinshu University, Dr.Eng. \\ $* * * * *$ CEO, Andeco inc., Dr.Eng.
}

Japan has rich forest resources, however, these resources have not been effectively utilized. It is therefore necessary to promote the utilization of forest resources in order to maintain multiple functions of forests and to sustainably manage the forests.

The enactment of "The Act on the Promotion of the Utilization of Wood in Public Buildings" and widespread popularity of pre-cut wood has resulted in a growing demand for quality wood. Therefore, in order to promote the use of domestic timber, it is necessary to distribute timber whose qualities such as area of production and strength have been revealed. For that reason, it is necessary to develop a wood traceability system.

The wood traceability system was tested in 8 areas in Japan, and the method and effectiveness of the system were clarified. However, due to its low cost-effectiveness, the wood traceability system has not been widely used.

In this study, in order to improve the method of the wood traceability system, we conducted tests in 4 areas; Neba Village and Shinano Town in Nagano Prefecture, Kamo City in Niigata Prefecture and Takayama City in Gifu Prefecture. Furthermore, we conducted hearing survey at each distribution process in order to extract the necessary information about the wood. From the tests, we verified that the electronic tag labels are useful in wood traceability, because there is no need to replace the tag in the process of producing timber. In addition, through the hearing survey, we obtained the necessary information about the wood that is required by forestry cooperatives $\mathrm{N}$ and $\mathrm{H}$, lumber market $\mathrm{H}$, and sawmill $\mathrm{N}$.

The forestry cooperatives required accurate information on amount of forest resources such as a diameter at breast height, tree height, and forest management history. It is advisable to grasp such information by linking it with the geographical information. The lumber market required information on the tree species, owner of the timber, legality of the timber, and area of production when receiving the timber and , tip-end diameters, length, blemish on the timber, bending on the timber when shipping the timber. The saw-mills required information on tree species, tip-end diameters, length, blemishes, bending, and production areas when receiving timber logs. The information required by the saw-mills before shipping timber included; timber dimensions, moisture content, strength, area of production, and aesthetics on the timber surface. The necessary information required when dealing with traceability is mostly on the area of production and legality of timber.

We considered a simple method of the wood traceability system based on the results obtained from the tests and hearing survey. Adopting the method of managing the timber in batches and tracking the wood from the lumber market to the intermediate lumber yard makes the wood traceability system simple and reduces the workload. Therefore, adopting the simple method would facilitate the proof of origin and legality of the timber. 